\title{
ANALISIS KEPUASAN KONSUMEN MINUMAN COKELAT NYOKLAT KLASIK DI KECAMATAN KOTA SUMENEP KABUPATEN SUMENEP
}

\author{
Wildanun Hamisati ${ }^{1}{ }^{*}$, RP. Much. Muchtar ${ }^{2)}$ \\ ${ }^{1)}$ Mahasiswa Prodi Agribisnis Fakultas Pertanian Unija, \\ email: wildaprastama@gmail.com \\ ${ }^{2)}$ Dosen Prodi Agribisnis Fakultas Pertanian Unija, \\ email: muchtar@wiraraja.ac.id
}

\begin{abstract}
ABSTRAK
Penelitian ini bertujuan untuk mengetahui variabel apa saja dan variabel yang dominan yang mempengaruhi kepuasan konsumen. Variabel yang diteliti adalah kualitas produk (X1), harga (X2), citra merek (X3), rasa (X4), dan kualitas pelayanan (X5). Jenis penelitian adalah deskriptif dan kuantitatif. Penelitian dilakukan di tiga kedai Nyoklat Klasik di Kecamatan Kota Sumenep dengan menggunakan kusioner. Ukuran sampel yang diambil sebanyak 100 orang responden dengan metode aksidental sampling. Metode analisis yang digunakan adalah regresi linier berganda.

Hasil penelitian diperoleh persamaan duga regresi linier berganda yang terbentuk adalah $\mathrm{Y}=4,769+0,123 \mathrm{X}_{1}+0,224 \mathrm{X}_{2}+0,097 \mathrm{X}_{3}+0,058 \mathrm{X}_{4}+0,300 \mathrm{X}_{5}+\mathrm{e}$. Hasil penelitian menunjukkan bahwa variabel yang mempengaruhi kepuasan konsumen Nyoklat Klasik adalah kualitas pelayanan, dan variabel yang dominan mempengaruhi kepuasan konsumen Nyoklat Klasik adalah kualitas pelayanan.
\end{abstract}

Kata Kunci: Harga, Citra Merek, Kepuasan Konsumen, Kualitas Produk, Rasa, Kualitas Pelayanan.

PENDAHULUAN

Latar Belakang

Di era perekonomian modern, kepuasan konsumen menjadi hal yang wajib diperhatikan oleh perusahaan di tengah persaingan yang ketat.

Salah satu merek minuman 1. Variabel apayang mempengaruhi cokelat yaitu Nyoklat Klasik yang letaknya berada di Daerah Sumenep.Usaha minuman cokelat Nyoklat Klasik mendapatkan tantangan 2. agar mengetahui minat dan kesukaan konsumen sehingga konsumen tetap membeli produk tersebut dan tidak beralih pada produk lain. Berdasarkan latar belakang di atas perlu kiranya diketahui kepuasan konsumen minuman cokelat Nyoklat Klasik.

\section{Rumusan Masalah}

Berdasarkan latar belakang di atas dapat dirumuskan suatu masalah sebagai berikut :

kepuasan konsumen terhadap minuman cokelat Nyoklat Klasik di Kecamatan Kota Sumenep ?

Variabel apa yang dominan mempengaruhi terhadap kepuasan konsumen minuman cokelat Nyoklat Klasik di Kecamatan Kota Sumenep ?

\section{METODE PENELITIAN}

Jenis penelitian ini adalah 
penelitian deskriptif kuantitatif. Penelitian dilaksanakan pada bulan Maret sampai April 2019. Variabel yang digunakan ada dua jenis yaitu variabel terikat (dependent variable) dan variabel bebas (independent variable). Variabel terikat dalam penelitian ini adalah kepuasan konsumen (Y) dan variabel bebasnya adalah kualitas produk (X1), harga (X2), citra merek (X3), rasa (X61).,b dan kualitas pelayanan (X5).

Populasi dalam penelitian ini adalah konsumen Nyoklat Klasik yang membeli di tiga kedai Nyoklat Klasik yang dipilih. Sampel yang diambil menggunakan aksidental sampling.

Menurut Hair et al., 1998 (dalam

Ulum, 2011:74) penentuan jumlah sampel yaitu antara jumlah subjek dan jumlah variabel independen sekitar 15 hingga 20 subjek per variabel independen, sehingga sampel yang ditetapkan sebanyak 100 responden.

Pengujian instrument dilakukan dengan uji validitas dan uji reliabilitas. Pada uji validitas pertanyaan pada kusioner adalah valid apabila $r$ hitung $>$ $r$ tabel begitu pula sebaliknya. Pada uji reliabilitas dengan menggunakan rumus Alpha Chronbach, yaitu apabila variabel memberikan nilai Alpha Chronbach > 0,60 , maka variabel tersebut reliable.

Metode analisis data yang digunakan adalah regresi linier berganda. Model regresi berganda disebut baik jika memenuhi asumsi normalitas dan dan terbebas dari asumsiasumsi klasik statistik lainnya seperti uji multikolinieritas, uji heteroskedastisitas, dan uji autokorelasi.

Perhitungan analisis data menggunakan bantuan program komputer pengolah statistik yaitu SPSS.
Terdapat lima variabel bebas dalam penelitian ini, sehingga persamaan regresi yang digunakan adalah sebagai berikut:

$\mathrm{Y}=\alpha+\mathrm{b} 1 \mathrm{X} 1+\mathrm{b} 2 \mathrm{X} 2+\mathrm{b} 3 \mathrm{X} 3+\mathrm{b} 4 \mathrm{X} 4+$ b5X5

Keterangan:

$\mathrm{Y} \quad=$ Kepuasan konsumen

$\alpha \quad=$ Konstanta

$5=$ Koefisien regresi variabel

bebas

$\mathrm{X} 1=$ Kualitas Produk

$\mathrm{X} 2=$ Harga

$\mathrm{X} 3=$ Citra merek

$\mathrm{X} 4=$ Rasa

X5 = Kualitas pelayanan

Selanjutnya pengujian hipotesis dengan menggunakan uji $F$ dan uji t. Uji $\mathrm{F}$ digunakan untuk menguji pengaruh variabel bebas terhadap variabel terikat secara bersama-sama. Taraf nyata yang digunakan $(\alpha)$ sebesar $5 \%$ dengan derajat kebebasan df $=(\mathrm{k} ; \mathrm{n}-\mathrm{k})$. Bila nilai probabilitas F-hitung kurang dari 5\% maka keputusan yang di ambil adalah menolak Ho dan menerima Ha. Bila F-hitung < F-tabel, maka Ho diterima dan Ha ditolak. Sebaliknya, bila F-hitung $\geq$ F-tabel maka Ho di tolak dan Ha diterima.

Uji $\mathrm{t}$ dilakukan untuk menguji pengaruh-pengaruh variabel bebas terhadap variabel terikat secara parsial (individual). Taraf nyata yang digunkan ( $\alpha$ ) sebesar 5\% dengan derajat kebebasan : $\mathrm{df}=\mathrm{t}(\alpha / 2 ; \mathrm{n}-\mathrm{k}-1)$. Bila nilai probabilitas dari t-hitung kurang dari 5\% maka keputusan yang diambil adalah menolak Ho dan menerima Ha. Bila t-hitung < t-tabel, maka H0 diterima dan Ha ditolak,Sebaliknya bila t-hitung $\geq$ t-tabel maka Ha diterima. 
HASIL PENELITIAN DAN PEMBAHASAN

Regresi Linier Berganda

Hasil dari penelitian dengan

Tabel 1.1 Uji Regresi Linier Berganda

\begin{tabular}{lc}
\hline IVariabel & $\begin{array}{c}\text { Nilai } \\
\text { Standar Koefisien }\end{array}$ \\
\hline Konstanta & 4,769 \\
Kualitas Produk & 0,123 \\
Harga & 0,224 \\
Citra Merek & 0,097 \\
Rasa & 0,058 \\
Kualitas Pelayanan & 0,300 \\
\hline
\end{tabular}

Sumber: Data Diolah (2019).

Berdasarkan Tabel 1.6 di atas diperoleh persamaan duga regresi linier berganda lima prediktor sebagai berikut: $\mathrm{Y}=4,769+0,123 \mathrm{X}_{1}+0,224 \mathrm{X}_{2}+$ $0,097 \mathrm{X}_{3}+0,058 \mathrm{X}_{4}+0,300 \mathrm{X}_{5}+\mathrm{e}$

\section{a. Uji Simultan (Uji F)}

Berdasarkan hasil penelitian diketahui nilai signifikansi untuk pengaruh kualitas produk (X1), harga $(\mathrm{X} 2)$, citra merek (X3), rasa (X4), dan kualitas pelayanan (X5) secara simultan program SPSS 22.0 diperoleh hasil seperti pada tabel berikut ini:

\section{b. Uji Parsial (Uji t)}

Hasil uji t pada penelitian ini dapat dilihat pada tabel di bawah ini.

Tabel 1.2 Uji t

\begin{tabular}{lll}
\hline Variabel & $\begin{array}{l}\text { Nilai } \\
\text { t-hitung }\end{array}$ & Nilai Signifikansi \\
\hline Kualitas Produk & 1,136 & 0,259 \\
Harga & 1,891 & 0,062 \\
Citra Merek & 0,865 & 0,389 \\
Rasa & 0,512 & 0,610 \\
Kualitas Pelayanan & 2,917 & 0,004
\end{tabular}

Sumber: Data Diolah (2019). 
Dari hasil penelitian diperoleh nilai $t$ tabel sebesar 1,989 pada $\alpha=5 \%$. Berdasarkan tabel uji t di atas dapat dijelaskan dari masing-masing variabel bebas sebagai berikut:

1) Pengaruh kualitas produk terhadap kepuasan konsumen minuman cokelat Nyoklat Klasik

Berdasarkan hasil perhitungan secara parsial pengaruh kualitas produk (X1) terhadap kepuasan konsumen ( $\mathrm{Y}$ ) diperoleh nilai $\mathrm{t}$ hitung sebesar $1,136<1,989$. Sehingga tidak terdapat pengaruh kualitas produk (X1) terhadap kepuasan konsumen minuman cokelat Nyoklat Klasik (Y). Untuk mencapai kualitas produk yang diinginkan maka diperlukan suatu standarisasi kualitas

2) Pengaruh harga terhadap kepuasan konsumen minuman cokelat Nyoklat Klasik

Berdasarkan hasil perhitungan secara parsial pengaruh harga (X2) terhadap kepuasan konsumen (Y) diperoleh nilai $\mathrm{t}$ hitung sebesar 1,891< 1,989. Sehingga tidak terdapat pengaruh harga (X2) terhadap kepuasan konsumen minuman cokelat Nyoklat Klasik (Y). Kesesuaian harga yang ditetapkan oleh perusahaan Nyoklat Klasik perlu dipertimbangkan kembali..

3) Pengaruh citra merek terhadap kepuasan konsumen minuman cokelat Nyoklat Klasik

Berdasarkan hasil perhitungan secara parsial pengaruh citra merek (X3) terhadap kepuasan konsumen (Y) diperoleh nilai $\mathrm{t}$ hitung sebesar $0,865<$ 1,989. Sehingga tidak terdapat pengaruh citra merek (X3) terhadap kepuasan konsumen minuman cokelat Nyoklat Klasik (Y). Hal ini dipengaruhi karena nama merek
Nyoklat Klasik kurang mudah untuk diingat.

4) Pengaruh rasa terhadap kepuasan konsumen minuman cokelat Nyoklat Klasik

Berdasarkan hasil perhitungan secara parsial pengaruh rasa (X4) terhadap kepuasan konsumen (Y) diperoleh nilai $\mathrm{t}$ hitung sebesar $0,512<$ 1,989. Sehingga tidak terdapat pengaruh rasa (X4) terhadap kepuasan konsumen minuman cokelat Nyoklat Klasik (Y). Hal ini dipengaruhi rasa dari minuman cokelat Nyoklat Klasik yang disajikan terkadang masih berubah-ubah untuk varian rasa yang sama sehingga kurang sesuai dengan selera mereka.

5) Pengaruh kualitas pelayanan terhadap kepuasan konsumen minuman cokelat Nyoklat Klasik

Berdasarkan hasil perhitungan secara parsial pengaruh kualitas pelayanan (X5) terhadap kepuasan konsumen (Y) diperoleh nilai thitung sebesar 2,917 > 1,989. Sehingga terdapat pengaruh kualitas pelayanan (X5) terhadap kepuasan konsumen minuman cokelat Nyoklat Klasik (Y). Hal ini dipengaruhi karena variabel kualitas pelayanan yang diterima konsumen sesuai dengan apa yang diharapkan.

\section{c. Koefisien Determinasi $\left(\mathbf{R}^{2}\right)$}

Berdasarkan hasil penelitian diperoleh nilai R Square sebesar 0,434. Nilai tersebut menunjukkan bahwa 43,4\% kepuasan konsumen dipengaruhi oleh kualitas produk, harga, citra merek, rasa, dan kualitas pelayanan. Sedangkan sisanya $56,6 \%$ dipengaruhi oleh variabel lain yang tidak diteliti dalam penelitian ini. 


\section{KESIMPULAN}

Berdasarkan hasil penelitian dan analisis yang telah dilakukan, maka diperoleh kesimpulan sebagai berikut:

1. Variabel yang berpengaruh terhadap kepuasan konsumen minuman cokelat Nyoklat Klasik (Y) di Kecamatan Kota Sumenep adalah variabel kualitas pelayanan (X5).

2. Variabel yang dominan mempengaruhi kepuasan konsumen minuman cokelat Nyoklat Klasik di Kecamatan Kota Sumenep adalah variabel kualitas pelayanan (X5).

\section{DAFTAR PUSTAKA}

Dwiastuti, R., 2017, "Metode Penelitian Sosial Ekonomi Pertanian: Dilengkapi Pengenalan Metode Penelitian Kuantitatif, Kualitatif, dan Kombinasi Kuantitatif Kualitatif", Cetakan Pertama, UB Press, Malang, Diakses https://books.google.co.id/book s?isbn=6024324332, $\quad[26$ Februari 2019].

Janie, D. N. A., 2012, "Statistik Deskriptif dan Regresi Linier Berganda dengan SPSS", Semarang University Press, Semarang, Hal. 13, Diakses pada http://repository.usm.ac.id/files /bookusm/B208/201705190222 09Statistik-Deskriptif-\&-

Regresi-Linier-Bergandadengan-SPSS.pdf, [26 Februari 2019].

Kaihatu, T. S., Daengs, A., dan Indrianto,

A. T.L.,2015, "Manajemen Komplain”, Edisi I, ANDI,
Yogyakarta,Diakses

https://books.google.co.id/book s?isbn=9792923969, $[22$ Februari 2019].

Kurniawati, D. Suharyono.

Kusumawati, A., 2014, "Pengaruh Citra Merek, Dan Kualitas Produk Terhadap Kepuasan Dan Loyalitas Pelanggan (Studi Pada Pelanggan KFC Cabang Kawi Malang)", Jurnal Administrasi Bisnis,Vol. $\quad 14, \quad$ No 2,Universitas Brawijaya, Malang, hal. 3-4, Diakses http://administrasibisnis.student journal.ub.ac.id/index.php/jab/a rticle/view/583 , [11 januari 2019].

Riyono, dan Budiharja, G. E., 2016, "Pengaruh Kualitas Produk, Harga, Promosi, Dan Brand Image Terhadap Keputusan Pembelian Produk AQUA", Jurnal STIE Semarang, Vol. 8, No. 2, STIE Semarang, Semarang, Diakses pada https://media.neliti.com/media/ publications/133954-IDpengaruh-kualitas-produkharga-promosi-d.pdf. Desember 2018].

Susanto, A. B., dan Wijarnoko, H., 2004, "Power Branding: Membangun Merek Unggul dan Organisasi Pendukungnya", Cetakan Pertama, Quantum Bisnis dan Manajemen, Jakarta Selatan, Diakses pada https://books.google.co.id/book s?isbn=9793758023, $\quad$ [25 Februari 2019]. 